\title{
SEXUalidade Na ESCOLA
}

\section{Valladares, K.K. (2001). Orientação Sexual na Escola. -2. ed. - Rio de Janeiro: Quartet, 128 p.}

Q presente livro foi fruto da experiência e da observação empírica da autora como professora, psicóloga e socióloga, envolvida com as questões sociais, afetivas e sexuais de seus alunos e clientes no consultório. Fundamentado nos Parâmetros Curriculares Nacionais, em sua segunda edição, tem a proposta de auxiliar e estimular o trabalho de educadores na escola quanto às questões relacionadas à sexualidade, de acordo com a nova Lei de Diretrizes e Bases (LBV 0.394/96), que regulamenta todo o processo educacional no país, e seguindo as orientações traçadas pelo MEC. Desta forma, a Orientação Sexual deve ser inserida na escola como tema transversal, tendo que perpassar todas as disciplinas da grade curricular: da história à educação artística, passando pela matemática, até chegar às outras áreas de conhecimento. A intenção é refletir acerca da importância da Orientação Sexual na escola para a construção da cidadania, de uma sociedade mais justa, feliz e para o desenvolvimento afetivo e sexual das pessoas.

O início do livro se dá com a apresentação do o Dr. José Leonardo Machado Vaz, que faz uma reflexão da situação da saúde e da educação nos investimentos do governo e cita que o Brasil é um país de desinformados e de mal informados, e as crianças e os adolescentes são os que mais sofrem nessa crise. Dentro deste parâmetro, o sexo continua sendo uma questão polêmica, envolta em superstições, tabus, preconceitos, ignorância, vergonha, repressão e falso moralismo. Justifica-se, assim, a inclusão da Orientação Sexual entre os fundamentos da educação, pois ninguém desconhece a imensa responsabilidade da escola na formação afetiva e emocional de seus alunos. Segundo o autor, a escola precisa atingir seus objetivos, ir ao encontro da comunidade, em busca do desenvolvimento harmonioso das crianças e dos jovens, valendo-se, sempre, de uma linguagem clara, objetiva, direta.

$\mathrm{Na}$ introdução, a autora do livro faz um pequeno apanhado sobre a história da humanidade em relação à sexualidade, citando que antigamente era um tabu falar sobre sexo, que por sua vez estava associado a coisas feias. Ao passar dos anos, a questionada revo- lução sexual se espalhou pelos meios de comunicação, ou foi por estes promovida, mas, ainda que isto tenha acontecido, existe um preconceito muito grande em se falar sobre a sexualidade, sobretudo dentro da escola. Como afirma a autora, a sexualidade é uma fonte de amor pela vida, uma forma definitiva de afirmação diante de si mesmo, dos outros e do mundo. E por que não falar sobre ela de modo a eliminar a rigidez e o moralismo excessivo? A formação sexual se inicia através das brincadeiras, com a definição de papéis: masculino e feminino, desde a infância, devendo o tema ser tratado de forma mais ampla, de modo a abranger aspectos psicossociais, culturais e políticos. A sexualidade domina toda a atividade humana desde a arte, a literatura, o cinema, a imprensa e a televisão. Não falar sobre ela resultará em total alienação às transformações existentes no mundo.

No primeiro capítulo, intitulado "Orientação Sexual", a autora faz uma diferenciação entre orientação sexual e educação sexual, uma vez que esta última diz respeito à experiência pessoal e ao conjunto de valores transmitidos pela família e pelo ambiente social nas questões relativas à sexualidade, enquanto que a orientação sexual é um processo formal e sistematizado, que acontece dentro da instituição escolar, e constitui-se, portanto, em uma proposta objetiva de intervenção por parte dos educadores. Esta não substitui a família mas a complementa, de forma que são diferentes os tratamentos dados à questão da sexualidade no espaço privado da família e no espaço público da escola. Diante de tais argumentos, nunca é demais repetir que a orientação sexual se faz urgentemente necessária. Aliada à família, a escola pode proporcionar ao estudante um desenvolvimento mais equilibrado, contribuindo assim para evitar os acidentes sexuais.

A justificativa a respeito da importância da realização da orientação sexual na escola é abordada no segundo capítulo, no qual a autora cita que a escola deve informar e discutir os diferentes tabus, preconceitos, crenças e atitudes existentes na sociedade, buscando, senão uma isenção total, o que é difícil de con- 
seguir, pelo menos uma condição de maior distanciamento por parte dos professores para empreender essa tarefa, abordando todas as mensagens transmitidas pela mídia, família e pela sociedade. É preciso desenvolver uma atitude mais positiva em relação ao sexo, pois vivemos em época de transição, onde os acidentes sexuais continuam acontecendo, e o índice de pessoas contaminadas pelo vírus da AIDS e DST crescem. Quando a falta de orientação adequada deixa de ser apenas uma deficiência em nossa sociedade, ela se transforma num problema que exige soluções urgentes, por isso a autora faz uma reflexão para o papel da escola, pais e profissionais da educação a respeito da importância de solucionar as questões relacionadas à sexualidade para crianças e adolescentes e para a respectiva mudança de comportamento.

A justificativa para segunda edição deste livro, como citado anteriormente, trata da inserção da "Orientação Sexual" no currículo, que deve se dar no âmbito pedagógico, não tendo, portanto, um caráter de aconselhamento individual do tipo psicoterapêutico, e sem discriminar o espaço público do privado, orientando crianças e jovens. A autora tem como objetivo principal neste trabalho as mudanças nos padrões de comportamento, levando-se em conta três aspectos fundamentais: a transmissão de informações de maneira verdadeira; a eliminação do preconceito; a atuação na área afetivo-emocional, para que crianças e jovens possam desenvolver e exercer sua sexualidade com prazer e responsabilidade. Os conteúdos de Orientação Sexual podem e devem ser flexíveis, de forma a abarcarem as necessidades específicas de cada turma, com o objetivo de situar o sexo num contexto mais amplo de relacionamento entre os seres humanos, num contexto bio-psico-sócio-cultural. Apesar disto, o presente livro se diferencia dos demais ao trazer um programa de apoio com sugestões de enfoques temáticos para reflexões, com diferentes turmas, desde a primeira série do ensino fundamental até a terceira série do ensino médio. Muitos autores acham isto desnecessário, pois sobre sexualidade não existem regras. Mas, para profissionais que não estão preparados para este tipo de trabalho, um programa de apoio é de extrema importância para dar o primeiro passo à mudança de atitude em relação à sexualidade, com menos insegurança e mais responsabilidade. $\mathrm{O}$ profissional de orientação sexual nunca deve colocar sua opinião como verdade absoluta, inquestionável, e sim, deixar que o grupo chegue às suas próprias conclusões, coordenando as idéias e não direcionando as questões, podendo ser utilizadas diversas técnicas para este trabalho como: dinâmica de grupo, teatro, desenhos, discussões em grupos, folhetos informativos etc. Antes de iniciar o trabalho, segundo a autora, devese fazer uma reunião com todo corpo docente da escola, funcionários e principalmente com os pais, para esclarecer como funcionará o trabalho e explicar que inicialmente o orientador deve fazer um levantamento das questões e temas de maior interesse da turma, para que depois possa se estabelecer às regras que deverão ser seguidas durante o andamento do curso. O papel da escola é dar orientação sexual ao aluno e não educação sexual. A sexualidade de inscreve no espaço escolar, não apenas nas portas dos banheiros e paredes. Ela se manifesta no comportamento dos alunos dentro da sala de aula e fora dela. Querendo ou não, é na escola que surgem as mais diversas situações nas quais o educador é chamado a intervir, com isso pode-se afirmar que a implantação da orientação sexual nas escolas contribui para o bem-estar das crianças e jovens na vivência de sua sexualidade atual e futura.

A autora esclarece a importância de encontros com os pais para se discutir os temas sugeridos pelos próprios filhos e para explicar a responsabilidade deles junto à escola, deixando bem claro que a escola é uma aliada para a mudança de atitude frente à sexualidade e não a única responsável para que isto aconteça.

O terceiro capítulo consta de um material de consulta para os educadores de orientação sexual, que cita temas como: o corpo, sexualidade infantil, puberdade, anatomia sexual, menstruação, fecundação, gestação, parto, anticoncepção, DST e sexualidade do deficiente mental. Esclarece, ainda, que este trabalho não tem a intenção de avaliar os alunos a partir de notas, e sim a avaliação subjetiva do trabalho (desenvolvimento).

O livro apresenta diversidade do tema Orientação Sexual de uma maneira didática, clara e objetiva, pondo em reflexão e discussão várias posturas de educadores ao tratar de sexo e sensibilizando profissionais, pais e funcionários. É preciso informar jovens e crianças para que eles entendam e sejam capazes de integrálas à sua visão de mundo. É necessário mais que informação, é preciso liberdade de expressão!

\section{Flávia Nunes de Moraes Beraldo Univesidade São Francisco}

